\title{
1 Development and Testing of a Novel Sulfur Dioxide Sonde
}

2 Subin Yoon ${ }^{1}$, Alexander Kotsakis ${ }^{1,2}$, Sergio L. Alvarez ${ }^{1}$, Mark G. Spychala ${ }^{3,4}$, Elizabeth Klovenski ${ }^{1}$, Paul 3 Walter $^{3}$, Gary Morris ${ }^{3,5}$, Ernesto Corrales ${ }^{6}$, Alfredo Alan ${ }^{6}$, Jorge Andres Diaz ${ }^{6,7}$, James H. Flynn ${ }^{1}$

$4 \quad{ }^{1}$ Department of Earth and Atmospheric Sciences, University of Houston, Houston, TX, 77004, USA

$5 \quad{ }^{2}$ now at ERT, Inc., Laurel, MD, 20707, USA

$6 \quad{ }^{3}$ St. Edward's University, Austin, TX, 78704, USA

$7 \quad{ }^{4}$ now at Hamelmann Communications, Pagosa Springs, CO, 81147, USA

$8 \quad{ }^{5}$ now at NOAA Global Monitoring Laboratory, Boulder, CO, 80305, USA

$9 \quad{ }^{6}$ GasLAB, CICANUM. Universidad de Costa Rica, San José, Costa Rica

$10{ }^{7}$ now at INFICON, East Syracuse, NY, 13057, United States

11

12

Correspondence to: James H. Flynn (jhflynn@central.uh.edu) 
Abstract. A novel technique has been developed to measure sulfur dioxide $\left(\mathrm{SO}_{2}\right)$ using a modification of the existing electrochemical concentration cell (ECC) ozonesonde technology. The current sonde-based method to measure $\mathrm{SO}_{2}$ (i.e. the dual-sonde approach) involves launching two ozonesondes together with one of the sondes having a filter to remove $\mathrm{SO}_{2}$ at the inlet. The $\mathrm{SO}_{2}$ profile is determined by taking the difference between the measurements from the two instruments. The dual-sonde method works well in typical tropospheric conditions when $\left[\mathrm{O}_{3}\right]>\left[\mathrm{SO}_{2}\right]$ but saturates when $\left[\mathrm{SO}_{2}\right]>\left[\mathrm{O}_{3}\right]$ and has large uncertainties in the upper troposphere/lower stratosphere that would limit its effectiveness in measuring $\mathrm{SO}_{2}$ from an explosive volcanic eruption. Due to these limitations, several modifications were made to create a single-sonde system that would directly measure $\mathrm{SO}_{2}$ (i.e. the $\mathrm{SO}_{2}$ sonde). These modifications included (1) a positively biased ECC background current, (2) the addition of an $\mathrm{O}_{3}$ removal filter, and (3) the addition of a sample dryer. The $\mathrm{SO}_{2}$ sonde measures $\mathrm{SO}_{2}$ as a reduction in the cell current. There was a strong correlation $\left(\mathrm{r}^{2}>0.94\right)$ between the $\mathrm{SO}_{2}$ sonde and a Thermo $43 c$ analyzer during controlled laboratory tests and pre-flight tests. Varying humidity levels affected the $\mathrm{SO}_{2}$ sonde's sensitivity $(84.6 \pm 31.7 \mathrm{ppbv} / \mu \mathrm{A}, 1 \sigma=$ $37 \%$ ) during initial field tests, which was resolved by adding a sample dryer upstream of the $\mathrm{O}_{3}$ removal filter and pump inlet. This modification significantly reduced the variability and increased the sensitivity of the $\mathrm{SO}_{2}$ measurements $(47 \pm 5.8$ $\mathrm{ppbv} / \mu \mathrm{A}, 1 \sigma=12 \%$ ). Field tests included measurements near Kîlauea Volcano (before and during the 2018 eruption of the Lower East Rift Zone), Costa Rica's Turrialba Volcano, and anthropogenic plumes from the Athabasca Oil Sands region of Alberta, Canada. This single $\mathrm{SO}_{2}$ sonde system is an effective, inexpensive instrument for measuring both ground-based and vertical profiles of $\mathrm{SO}_{2}$ from anthropogenic and natural sources (i.e. volcanic eruptions) over a wide range of concentrations.

\section{Introduction}

Sulfur dioxide $\left(\mathrm{SO}_{2}\right)$ emissions result from anthropogenic activities, such as power generation and crude oil refining processes, and natural sources, such as volcanoes. In gas form, $\mathrm{SO}_{2}$ acts as a respiratory irritant leading to complications with asthma and cardiovascular conditions (Chen et al., 2007; Sunyer et al., 2003; Tzortziou et al., 2015, 2018). Gaseous $\mathrm{SO}_{2}$ can be converted to sulfate aerosols (Zhang et al., 2015), which are highly scattering, reduce visibility, and can have a cooling effect on the climate when injected into the stratosphere (Kiehl and Briegleb, 1993; Schmidt et al., 2010). $\mathrm{SO}_{2}$ acidifies rain, accelerating damage of infrastructure and vegetation, particularly near $\mathrm{SO}_{2}$ sources such as volcanoes (Delmelle et al., 2002; Krug and Frink, 1983; Tortini et al., 2017). Due to these various climate, environmental, and human health-related impacts, anthropogenic $\mathrm{SO}_{2}$ has been heavily monitored (Shannon, 1999; Zhang and Schreifels, 2011), and regulations have been enacted to reduce these emissions (EPA, 2000).

The largest natural sources of $\mathrm{SO}_{2}$ are volcanoes. The eruption of Mt. Pinatubo in the Philippines in June 1991 had global climatic effects and significant impacts on the tropospheric and lower stratospheric composition (Bluth et al., 1992; Parker et al., 1996). Apart from such catastrophic eruptions, $\mathrm{SO}_{2}$ can be continually emitted from volcanoes. $\mathrm{SO}_{2}$ plumes from over 90 volcanoes have been reliably detected by satellites, resulting in the injection of an estimated $23 \pm 2 \mathrm{Tg} \mathrm{yr}^{-1} \mathrm{of} \mathrm{SO}_{2}$ into the 
atmosphere (Carn et al., 2017). However, unlike anthropogenic sources of $\mathrm{SO}_{2}$, most volcanoes lack routine ground monitoring (Galle et al., 2010; Pieri et al., 2013) and few opportunities exist for routine validation of satellite retrievals of $\mathrm{SO}_{2}$ with in situ measurements. Unmanned aerial vehicle (UAV) platforms can measure volcanic plumes at altitudes of $2 \mathrm{~km}$ above the takeoff altitude(Galle et al., 2010; Diaz et al., 2015). However, the lack and difficulty of monitoring and the possibility of another stratospheric injection of $\mathrm{SO}_{2}$ motivated the development of an inexpensive but reliable balloon-borne instrument that could be deployed quickly after an eruption to validate satellite observations with in situ measurements.

Radiosondes and ozonesondes have been widely used for measurements of various atmospheric parameters (e.g. temperature, air pressure, relative humidity [RH], and wind speed and direction) and $\mathrm{O}_{3}$ concentrations, respectively. These measurements produce vertical $\mathrm{O}_{3}$ profiles and allow for the validation of satellite based $\mathrm{O}_{3}$ vertical column density (VCD). The current sonde-based method for measuring $\mathrm{SO}_{2}$, the dual-sonde method, uses two En-Sci (Environmental Science Inc., Westminster, $\mathrm{CO}$ ) ozonesondes in tandem (Morris et al., 2010). For the dual-sonde method, an $\mathrm{SO}_{2}$ removal filter is placed at the pump inlet of one of the ozonesondes, scrubbing $\mathrm{SO}_{2}$ from the sampled air before it enters the electrochemical concentration cell (ECC). The other sonde samples unfiltered air (i.e. air containing both $\mathrm{SO}_{2}$ and $\mathrm{O}_{3}$ ). Due to the chemical reactions in the cathode cell, the filtered sonde measures $\mathrm{O}_{3}$, while the unfiltered sonde measures the difference between $\mathrm{O}_{3}$ and $\mathrm{SO}_{2}\left(\left[\mathrm{O}_{3}\right]-\left[\mathrm{SO}_{2}\right]\right)$ since $\mathrm{SO}_{2}$ has an equal (relative to $\mathrm{O}_{3}$ ) but negative signal in the ECC (Morris et al., 2010). The $\mathrm{SO}_{2}$ concentrations are then determined from the difference between the two sonde measurements. This method works well in the troposphere when the $\mathrm{SO}_{2}$ concentration is less than the $\mathrm{O}_{3}$ concentration, but not as well in intense plumes, such as those found in eruptive volcanic environments. When the $\mathrm{SO}_{2}$ concentration exceeds the $\mathrm{O}_{3}$ concentration, the cell current in the unfiltered sonde becomes zero. The excess $\mathrm{SO}_{2}$ saturates the dual-sonde and distorts the calculated $\mathrm{SO}_{2}$ profile. Additionally, in the stratosphere, where the $\mathrm{O}_{3}$ signal grows much larger than in the troposphere, the combined uncertainty of the measurements of the filtered and unfiltered sondes results in a large lower limit of detection (LLOD), on the order of tens of ppbv. Thus, a field deployment of the dual-sonde method more than a few days after an explosive, tropical volcanic eruption such as Mt. Pinatubo would result in little useful data in the critical upper troposphere/lower stratosphere region.

This study reports on the development of a single instrument capable of in situ $\mathrm{SO}_{2}$ measurements in the presence or absence of $\mathrm{O}_{3}$. This sonde can measure $\mathrm{SO}_{2}$ at much greater concentrations than $\mathrm{O}_{3}$ without saturating the system and can be configured for a sub-ppbv LLOD (calculated using $3 \sigma$ ) at sea level. Since $\mathrm{O}_{3}$ is removed from the sample stream, this $\mathrm{SO}_{2}$ sonde avoids the compounded errors of the dual-sonde method. Field deployments of the $\mathrm{SO}_{2}$ sonde include sampling of volcanic emissions from Kīlauea on the Big Island of Hawai'i, U.S., Turrialba Volcano in Costa Rica; and the emissions from petroleum extraction and processing at the Athabasca Oil Sands, Canada. Results from these field tests, covering a wide range of $\mathrm{SO}_{2}$ concentrations from both natural and anthropogenic emission sources, are described below. The $\mathrm{SO}_{2}$ sonde has been used for tethered and free-release balloons but can also be adapted for UAV platforms. 


\section{Instrumentation}

\subsection{Ozonesondes}

The standard and modified ECC En-Sci ozonesondes were used for the $\mathrm{O}_{3}$ and $\mathrm{SO}_{2}$ sonde measurements in this study. The basic functioning of the ECC ozonesonde is described in Komhyr (1969) and Morris et al.(2010). The ECC sensor is composed of platinum cathode and anode electrodes, each in its own cell, immersed in a diluted and saturated solution of potassium iodide (KI), respectively. The cells are connected by an ion bridge allowing for the transfer of electrical charges while maintaining the separation of the solutions (Eq. 1 and 2). When the cells are charged with the solution, a transient potential difference is generated but dissipated through the redistribution of charge across the ion bridge. The following equilibria are established from these reactions:

$893 I^{-} \rightleftharpoons I_{3}^{-}+2 e^{-}$(anode)

$90 \quad I_{2} \rightleftharpoons 2 e^{-} \rightarrow 2 I^{-}$(cathode)

Sampled air is diffused into the cathode cell, and the presence of $\mathrm{O}_{3}$ initiates a reaction (Eq. 3 ) that causes an imbalance in favor of $\left[I_{2}\right]$ in the cathode solution.

$2 \mathrm{KI}+\mathrm{O}_{3}+\mathrm{H}_{2} \mathrm{O} \rightarrow 2 \mathrm{KOH}+\mathrm{I}_{2}+\mathrm{O}_{2}$

95 To rebalance the cell, the iodine/iodide redox reactions in Ep. 4 and 5 result in a flow of electrons from the anode to the cathode 96 via the ion bridge. This cell current, measured by an external ammeter, is proportional to the $\mathrm{O}_{3}$ concentration.

$97 \quad 3 I^{-} \rightarrow I_{3}^{-}+2 e^{-}$(anode)

$I_{2}+2 e^{-} \rightarrow 2 I^{-}$(cathode)

As is also described in in Komhyr (1969) and Morris et al.(2010), when $\mathrm{SO}_{2}$ is present in the sample air, an additional reaction (Eq. 6) occurs in the cathode cell of the ECC, supplying the two electrons needed to rebalance the cathode cell after the $\mathrm{O}_{3}$ 101 reaction (Eq. 3).

$102 \mathrm{SO}_{2}+2 \mathrm{H}_{2} \mathrm{O} \rightarrow 2 \mathrm{SO}_{4}^{2-}+4 \mathrm{H}^{+}+2 e^{-}$

103 Thus, each $\mathrm{SO}_{2}$ molecule in the sampled air has the effect of cancelling the measurement of one $\mathrm{O}_{3}$ molecule. In effect, the 104 standard ECC ozonesonde reports $\left[\mathrm{O}_{3}\right]-\left[\mathrm{SO}_{2}\right]$ for its measurement. In most places and at most times, $\left[\mathrm{SO}_{2}\right]<<\left[\mathrm{O}_{3}\right]$, so there is not a significant impact on the $\mathrm{O}_{3}$ measurements, but in places downwind of $\mathrm{SO}_{2}$ sources (e.g. coal-burning power plants or volcanos), the $\mathrm{O}_{3}$ measurement will be negatively impacted. 


\subsection{Instrumentation}

Several $\mathrm{SO}_{2}$ and $\mathrm{O}_{3}$ instruments were used for validation of the $\mathrm{SO}_{2}$ sonde during laboratory and field testing. A calibration system was used to produce controlled concentrations of $\mathrm{SO}_{2}$ and $\mathrm{O}_{3}$. The calibration system relied on the operation of flow controllers or restrictors, an $\mathrm{SO}_{2}$ ultra-high purity (UHP) gas cylinder (4.87 ppm; Scott-Marrin, Inc., Riverside, CA) and/or a U.V. Photometric $\mathrm{O}_{3}$ calibrator (49C PS; Thermo Fisher Scientific, Franklin, MA), and zero air to produce desired pre-set concentration of $\mathrm{SO}_{2}$ and/or $\mathrm{O}_{3}$. The zero-air setup used for the field and laboratory testing was achieved using a dry zero air UHP gas cylinder or else generated by scrubbing ambient air through activated charcoal and Purafil SP (Purafil, Inc., Doraville, GA) canisters. The Thermo 43i-TL SO 2 analyzer(LLOD: 60-90 pptv at $5 \mathrm{~m}$ averaging) and the $49 \mathrm{i}_{3}$ analyzer (LLOD: 1.5 ppbv at $5 \mathrm{~m}$ averaging) were also used during laboratory testing, while a Thermo $43 c-\mathrm{TL} \mathrm{SO}_{2}$ analyzer was used during field testing in Hawai'i. These instruments were set to report $10 \mathrm{~s}$ average measurements.

\section{Single-sonde $\mathrm{SO}_{2}$ System and Laboratory Testing}

\section{1 $\mathrm{SO}_{2}$ sonde system description}

The first version (version 1.0) of the single-sonde $\mathrm{SO}_{2}$ system (i.e. $\mathrm{SO}_{2}$ sonde v1.0) included two major modifications to the En-Sci ECC ozonesonde: (1) the application of a positively biased background current to the cathode cell and (2) the addition of an $\mathrm{O}_{3}$ removal filter. In a standard $\mathrm{ECC}, \mathrm{O}_{3}$ produces a positive response signal while $\mathrm{SO}_{2}$ produces a negative signal when sufficient $\mathrm{O}_{3}$ (i.e. positive signal) is present. With these modifications, $\mathrm{SO}_{2}$ can be measured directly as the reduction of the cell current from the pre-set biased background current (Flynn and Morris, 2020). Unlike the dual-sonde system, this approach allows for direct $\mathrm{SO}_{2}$ measurements rather than an inference by subtraction of signals from two separate instruments. All components of the $\mathrm{SO}_{2}$ sonde fit within a standard ozonesonde foam box (approximately 8" x 8 " x 10") except for the inlet filter. The free-release balloon payload's total mass is approximately $1 \mathrm{~kg}$. The patent publication provides a detailed description and schematic of the $\mathrm{SO}_{2}$ sonde (Flynn and Morris, 2020).

\subsection{Testing of background current}

The background bias current is supplied by inserting an additional platinum electrode in the cathode cell powered by a $9 \mathrm{~V}$ battery (Flynn and Morris, 2020). To maintain consistent power, the circuit uses a 5V regulator. Varying the resistor installed in series with the battery and the electrode allows for a range of bias currents to be introduced. Laboratory tests compared the $\mathrm{SO}_{2}$ sonde measurements (initially configured without an $\mathrm{O}_{3}$ removal filter) to those made by a $43 i-\mathrm{TL} \mathrm{SO}_{2}$ analyzer (Fig. 1 , Table 1). $\mathrm{O}_{3}$ and $\mathrm{SO}_{2}$ gases were introduced using the laboratory calibration setup and a manifold to allow the sonde and the Thermo trace gas instruments to sample the same air. Results in Fig. 1 show $60 \mathrm{~s}$ averaged data. The test included (A) input of $\mathrm{O}_{3}$ without an added background current; (B) the same input of $\mathrm{O}_{3}$ with the addition of a background current (equivalent to a signal of approximately $90 \mathrm{ppbv}$ ); and the addition of $\mathrm{SO}_{2}$ to the $\mathrm{O}_{3}$ with the enhanced background signal where the $\mathrm{SO}_{2}$ 
concentration was either $(C)$ smaller or (D - E) larger than the $\mathrm{O}_{3}$ concentration. During (A), measurements made by $\mathrm{O}_{3}$ and $\mathrm{SO}_{2}$ sondes compare well to measurements made by the Thermo instruments (Fig.1, Table 1). The test included (E) the response of the $\mathrm{SO}_{2}$ sonde with a stepwise reduction of the $\mathrm{O}_{3}$ concentration resulting in an equivalent decrease in signal, followed by $(\mathrm{G}-\mathrm{I})$ a stepwise reduction in the $\mathrm{SO}_{2}$ concentration resulting in an equivalent increase in signal. At $(\mathrm{F})$, the $\mathrm{SO}_{2}$ concentration exceeded the biased background current ( $90 \mathrm{ppbv})$, resulting in no sonde response. During the full test, the sonde successfully measured $\mathrm{SO}_{2}$ both with and without $\mathrm{O}_{3}$ with approximately $97 \%$ efficiency.

Examination of the $\mathrm{SO}_{2}$ sonde data showed that noise was proportional to the measured signal, with 1- $\sigma$ noise at approximately $0.2-0.3 \%$ of the measured signal. Because increases in the $\mathrm{SO}_{2}$ concentration result in a decrease in the signal (i.e. lower cell currents), the magnitude of the applied background current bias determines the saturation point (i.e. upper limit of detection [ULOD]) of the $\mathrm{SO}_{2}$ sonde; saturation occurs when the measured cell current drops to zero. Applying a higher background current increases the ULOD but also increases noise and the LLOD. During laboratory testing, the LLOD ( $3 \sigma$ ) was calculated for a range of applied background current bias $(0.25$ to $10.0 \mu \mathrm{A})$. The LLOD for the varying bias current of 0.25 to $10.0 \mu \mathrm{A}$ ranged from approximately 0.002 to $0.084 \mu \mathrm{A}$, respectively.

\subsection{Testing of $\mathrm{O}_{3}$ removal filter}

Since the ECC responds to both $\mathrm{O}_{3}$ and $\mathrm{SO}_{2}$, an $\mathrm{O}_{3}$ removal filter was developed to remove interference from $\mathrm{O}_{3}$ in the sample. This proprietary $\mathrm{O}_{3}$ removal filter is placed upstream of the sonde inlet (Flynn and Morris, 2020). During laboratory testing, the $\mathrm{O}_{3}$ removal filter was exposed to a continual concentration of $487 \pm 3$ ppbv of $\mathrm{O}_{3}$ and a varying concentration of $\mathrm{SO}_{2}$ ranging from 0 to $111 \pm 1 \mathrm{ppbv}$ (Fig. 2). The $\mathrm{O}_{3}$ was effectively and consistently removed from the sampled air by the $\mathrm{O}_{3}$ removal filter during a stepwise dilution of $\mathrm{SO}_{2}$. The testing included measurements with (white background) and without (gray background) the $\mathrm{O}_{3}$ removal filter. The $\mathrm{SO}_{2}$ and $\mathrm{O}_{3}$ concentrations measured by the Thermo $43 i$-TL and $49 i$ instruments, respectively, and changes in $\mathrm{SO}_{2}$ dilution levels are also indicated in Fig. 2. The $\mathrm{O}_{3}$ removal filter destroyed the $\mathrm{O}_{3}$ at all $\mathrm{SO}_{2}$

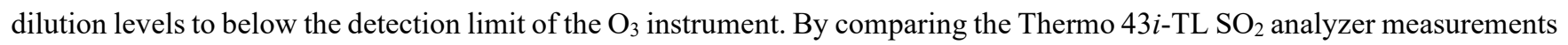
with and without the $\mathrm{O}_{3}$ removal filter, $\mathrm{SO}_{2}$ passed through the filter with $88 \%$ efficiency (Fig. S1a). The transmission efficiency was calculated by taking the ratio of $\mathrm{SO}_{2}$ measured by the sonde to the analyzer. The $\mathrm{SO}_{2}$ transmission efficiency increased to $97 \%$ when testing the $\mathrm{O}_{3}$ removal filter with the dry zero air UHP gas cylinder (Fig. S1b) instead of the zero air generator that processes ambient laboratory air (Fig. S1a). Additional testing of the $\mathrm{O}_{3}$ removal filter demonstrated that the $\mathrm{O}_{3}$ monitor. 


\section{Field Deployments, Part I}

This $\mathrm{SO}_{2}$ sonde $\left(\mathrm{SO}_{2}\right.$ sonde v1.0) was deployed and tested in Hawai'i and Costa Rica (Fig. S2). The field sites were close to active volcanoes, which are significant sources of natural $\mathrm{SO}_{2}$ (Tang et al., 2020; Carn et al., 2017). In Hawai'i, field measurements were made near Kîlauea Volcano on the south-eastern shore of Island of Hawai'i, the largest of Hawai'i's islands. Killauea is the youngest volcano on the island and one of Earth's most active volcanoes (Kern et al., 2015; Nadeau et al., 2015). Kîlauea had been in a state of eruption since 1983 (Patrick et al., 2019) with an average $\mathrm{SO}_{2}$ release rate of approximately 5,500 T/d measured during 2014 - 2017 (Elias et al., 2018). In Costa Rica, field measurements were made near Turrialba Volcano, one of the most active volcanoes in the Central American Volcanic Arc. Studies of emissions from Turrialba prior to 2013 reported $\mathrm{SO}_{2}$ release rates of up to 4,000 T/d (de Moor et al., 2016; Xi et al., 2016). Activity escalated after 2014, raising concerns for air quality and environmental health (de Moor et al., 2016; Tortini et al., 2017).

\subsection{Kïlauea, Hawai'i - February 2018}

The first deployment of the $\mathrm{SO}_{2}$ sonde v1.0 was during NASA's HyspIRI HyTES Hawaii Campaign (H3C) from February 310, 2018, near Kīlauea Volcano. The instrument was tested in flights on free-release and a tethered balloon system (TBS), and at ground level with measurements in Hawaii Volcanoes National Park (HVNP) downwind of Kīlauea's summit crater, Halema'uma'u. During the ground-level testing, an $\mathrm{SO}_{2}$ sonde and a Thermo $43 c-\mathrm{TL} \mathrm{SO}_{2}$ analyzer's sample inlet were mounted on the top of a van for co-located sampling.

Figure 3a depicts the measurements taken during the first encounter with an $\mathrm{SO}_{2}$ plume while driving through the $\mathrm{HVNP}$ on February 3, 2018. The strongly correlated $\mathrm{SO}_{2}$ sonde and Thermo 43c-TL measurements $\left(\mathrm{r}^{2}=0.99\right)$ reached upward of $\sim 940$ ppbv. The $\mathrm{SO}_{2}$ sonde had a sensitivity of $118.4 \pm 0.4 \mathrm{ppbv} / \mu \mathrm{A}$, determined by regression analysis of the sonde's cell current with the Thermo $43 c$-TL concentrations (Fig. 3a). $\mathrm{SO}_{2}$ sonde sensitivity varied significantly during the field deployment. During surface measurements on February 10, 2018, earlier zero-air calibrations measured a sensitivity of $86.5 \pm 1.5 \mathrm{ppbv} / \mu \mathrm{A}$ while measurements during a $\mathrm{SO}_{2}$ plume event, with peak concentrations of up to $400 \mathrm{ppbv}$, the $\mathrm{SO}_{2}$ sonde's sensitivity was $73.9 \pm 0.6 \mathrm{ppbv} / \mu \mathrm{A}$ (Fig. 3b). Although the $\mathrm{SO}_{2}$ sonde sensitivity varied significantly in ten subsequent calibrations $(84.6 \pm$ $31.7 \mathrm{ppb} / \mu \mathrm{A}$ ), the measurements remained strongly correlated (range: $\mathrm{r}^{2}=0.94-0.99$ ). The variability in the sensitivity in the field was likely due to changes in the ambient $\mathrm{RH}$ impacting the $\mathrm{SO}_{2}$ transmission efficiency of the $\mathrm{O}_{3}$ removal filter. This hypothesis was further confirmed by laboratory RH testing and discussed in Sect. 5.

\subsection{Turrialba, Costa Rica (Dual-sonde versus $\mathrm{SO}_{2}$ sonde comparison)}

On March 23, 2018, the University of Houston/St. Edward's University team conducted a free release flight from the Universidad de Costa Rica's campus in San Jose (approximately $31 \mathrm{~km}$ downwind of Turrialba Volcano) consisting of a traditional $\mathrm{SO}_{2}$ dual-sonde payload (Morris et al., 2010) as well as the $\mathrm{SO}_{2}$ sonde v1.0. This flight provided the first direct in 
situ comparison of the two $\mathrm{SO}_{2}$ sonde methods. Figure 4 shows the response of the $\mathrm{SO}_{2}$ sonde v1.0 and the calculated $\mathrm{SO}_{2}$ dual-sonde profile. The dual-sonde $\mathrm{SO}_{2}$ method can only report concentrations of $\mathrm{SO}_{2}$ up to a maximum of the concentration of $\mathrm{O}_{3}$ present. Furthermore, because the $\mathrm{SO}_{2}$ concentration is determined by subtracting the signals from two instruments, its uncertainty is higher than the uncertainty of a measurement from a single instrument. When $\left[\mathrm{SO}_{2}\right]>\left[\mathrm{O}_{3}\right]$, the dual sonde's unfiltered ozonesonde signal goes to zero, as happened for the Turrialba sonde launch between 3 - $5 \mathrm{~km}$ (Fig. 4). The $\mathrm{SO}_{2}$ saturates the cathode solution in the unfiltered sonde, not recovering until enough ambient $\mathrm{O}_{3}$ has been processed to rebalance the cell, resulting in a distorted profile (Fig. 4). For this flight, the $\mathrm{SO}_{2}$ sonde was configured to its maximum range (ULOD of approximately $450 \mathrm{ppbv}$ ) and was able to capture both the small plume below $2 \mathrm{~km}$ above mean sea level (AMSL) (approximately $18 \mathrm{ppbv}$ ) as well as the primary plume between $3-4 \mathrm{~km}$ AMSL (approximately $230 \mathrm{ppbv}$ ). The $\mathrm{SO}_{2}$ sonde v1.0 was able to capture the full shape of the profile, including the peak values and structure of the plume. The $\mathrm{SO}_{2}$ sonde v1.0 reports the top of the plume around $4 \mathrm{~km} \mathrm{AMSL}$, whereas the dual-sonde remains saturated until closer to $5 \mathrm{~km} \mathrm{AMSL}$. Thus, the dual-sonde $\mathrm{SO}_{2}$ profiles, when saturated by high concentrations of $\mathrm{SO}_{2}$, erroneously appear to have a greater vertical extent. Further, the $\mathrm{SO}_{2}$ sonde v1.0 showed no interference from $\mathrm{O}_{3}$ from the surface to altitude at $24.4 \mathrm{~km} \mathrm{AMSL}$, with $\mathrm{O}_{3}$ concentrations in the stratospheric $\mathrm{O}_{3}$ layer reaching $>4 \mathrm{ppmv}$ (not shown), demonstrating the effectiveness of the $\mathrm{O}_{3}$ filter. The $\mathrm{SO}_{2} \mathrm{VCD}$ was $8.3 \mathrm{DU}$ (Dobson Units, $1 \mathrm{DU}=2.69 \times 10^{16}$ molecules $\mathrm{cm}^{-2}$ ) for the $\mathrm{SO}_{2}$ sonde but was only $3.4 \mathrm{DU}$ for the dual-sonde measurement. Thus, once saturated, the dual-sonde method may underestimate the $\mathrm{SO}_{2} \mathrm{VCD}$. Additional laboratory testing is planned to resolve this discrepancy.

\section{Post Field Test Improvements and Laboratory Testing}

217 The variability in the $\mathrm{SO}_{2}$ sonde v1.0's sensitivity during the initial field tests was hypothesized to be due to varying levels of 218 humidity. $\mathrm{SO}_{2}$ is soluble in water and through multiphase reactions can be oxidized to sulfuric acid in the atmosphere in the 219 presence of water vapor (e.g. precipitation, clouds, fog, etc.) (Carmichael and Peters, 1979; Zhang et al., 2013; Terraglio and 220 Manganelli, 1967). Factors including liquid water content, aerosol composition, aerosol loading, and $\mathrm{pH}$ of the water are 221 important in determining adsorption and oxidation rate of $\mathrm{SO}_{2}$ (Liu et al., 2021). With increased humidity and presence of a filter, $\mathrm{SO}_{2}$ gas is likely adsorbing on the filter causing lower $\mathrm{SO}_{2}$ transmission efficiency due to potential uptake of $\mathrm{SO}_{2}$ in water on the filter. Several laboratory tests were done to confirm the need to remove water from the sample upstream of the $\mathrm{O}_{3}$ removal filter. A desiccant membrane dryer (Perma Pure LLC, Lakewood, NJ) composed of a Nafion ${ }^{\mathrm{TM}}$ tube in silica gel desiccant was placed in-line upstream of the $\mathrm{O}_{3}$ removal filter. This sample dryer is lightweight, relatively inexpensive, and does not require power.

Laboratory tests included exposing the $\mathrm{SO}_{2}$ sonde, with and without a sample dryer, to controlled levels of humidity and $\mathrm{SO}_{2}$. Without removing water vapor, the $\mathrm{SO}_{2}$ transmission efficiency decreases as humidity increases, particularly above $50 \% \mathrm{RH}$ 
filter. With the sample dryer in place, the $\mathrm{SO}_{2}$ transmission efficiency varies by an average of $<1 \%$ across a range of $0-85 \%$ RH (Fig. 5).

The dryer's useful lifetime was determined by continuously exposing it to high humidity $\left(>95 \% \mathrm{RH}\right.$ at approximately $\left.23{ }^{\circ} \mathrm{C}\right)$ sample stream. The downstream RH climbed from 5\% to $16 \%$ after $2.3 \mathrm{~h}$ and to $25 \%$ after $6.3 \mathrm{~h}$. At these downstream RH levels, the $\mathrm{SO}_{2}$ transmission efficiency remained above $95 \%$. A typical $\mathrm{SO}_{2}$ sonde's measurement time per flight, including pre-flight calibration, is approximately three hours. The dryer's useful lifetime is likely much longer than required for a flight since exposure to $95 \%$ RH conditions for several hours is highly unusual outside of hurricanes and tropical systems for balloon measurements. $\mathrm{SO}_{2}$ sonde and Thermo $43 c$-TL measurements were strongly correlated $\left(\mathrm{r}^{2}=0.99\right)$ during a multipoint calibration conducted using the $\mathrm{O}_{3}$ removal filter and the dryer under relatively high humidity levels. During that calibration, the $\mathrm{SO}_{2}$ sonde's sensitivity was $45.43 \pm 0.17 \mathrm{ppbv} / \mu \mathrm{A}$. By comparison, the average sensitivity during the $\mathrm{H} 3 \mathrm{C}$ campaign was $84.6 \pm 31.7 \mathrm{ppbv} / \mu \mathrm{A}$ across 10 sondes. The sample dryer, therefore, improved both the sensitivity and stability of the measurements observed.

\section{Field Deployments, Part II}

The updated $\mathrm{SO}_{2}$ sonde $\left(\mathrm{SO}_{2}\right.$ sonde v1.1) with the dryer filter was deployed and tested in Ft. McMurray, Canada, and again in Hawai'i in June 2018. Ft. McMurray is in the Alberta province of Canada and is home to the Athabasca Oil Sands, a large area of bitumen and heavy crude oil surface deposits high in sulfur content. Local processing of these products (e.g. surface mining) and resulting by-products (e.g. tailing ponds) can release significant amounts of $\mathrm{SO}_{2}$ into the atmosphere (Bari et al., 2020; McLinden et al., 2016; Simpson et al., 2010). A second field deployment to Hawai'i followed immediately after the deployment to Canada. On May 3, 2018, Kīlauea Volcano on Hawai'i entered a new eruptive phase with an outbreak of a series of fissures in the lower Puna area (Liu et al., 2021; Anderson et al., 2019; Gansecki et al., 2019; Patrick et al., 2020). The active phase volcanic gas emissions resulted in localized evacuations in the Lower East Rift Zone (LERZ) and poor air quality for much of the southern and western portions of the island (Tang et al., 2020). The eruption event entered a paused phase in early August, and was declared over on December 5, 2018 (Kern et al., 2020).

\subsection{Athabasca Oil Sands, Canada}

The $\mathrm{SO}_{2}$ sonde v1.1 was tested in Ft. MacKay (near Ft. McMurray; 57.1206 N, $111.4241^{\circ} \mathrm{W}$ ), Alberta, in the Athabasca Oil ground-based measurements. The $\mathrm{SO}_{2}$ sonde v1.1 was flown on the York TBS payload recording measurements from the ground to $300 \mathrm{~m}$ above ground level (AGL; $650 \mathrm{~m}$ AMSL). This deployment provided a dilute anthropogenic plume to test 
the $\mathrm{SO}_{2}$ sonde in a high-sensitivity, low-range configuration. The average sensitivity of the $\mathrm{SO}_{2}$ sonde $\mathrm{v} 1.1$ during the project was $51 \pm 1.2 \mathrm{ppbv} / \mu \mathrm{A}$. The $\mathrm{SO}_{2}$ sonde was configured to sample in a range from $\sim 0.5-25 \mathrm{ppbv}$ of $\mathrm{SO}_{2}$. The $\mathrm{TBS} \mathrm{SO}_{2}$ sonde's vertical profiles were averaged into $10 \mathrm{~m}$ altitude bins that measured $\mathrm{SO}_{2}$ concentration ranges that are more representative of anthropogenically-impacted $\mathrm{SO}_{2}$ rather than large volcanic plumes (Fig. 6). This field deployment also demonstrated the performance of the sonde at sub-ppbv levels of ambient $\mathrm{SO}_{2}$.

\subsection{Kīlauea, Hawai'i - June 2018}

In response to the larger eruption that started in May 2018, the $\mathrm{SO}_{2}$ sonde v1.1 was deployed to Hawai'i for the NASA-funded Big Island $\mathrm{SO}_{2}$ Survey (BISOS). The $\mathrm{SO}_{2}$ sonde launches occurred from Kahuku Ranch $\left(19.0549^{\circ} \mathrm{N}, 155.6934^{\circ} \mathrm{W}\right)$ and Na'alehu Elementary School (19.0610 N, $\left.155.5788^{\circ} \mathrm{W}\right)$ approximately $90 \mathrm{~km}$ downwind of Kīlauea's LERZ (Fig. S2d). The site's distance from the source allowed the plume to disperse and dilute as compared with measurements at the vent. $\mathrm{An}^{\mathrm{SO}_{2}}$ plume was detected during seven of the nine free-release balloon launches during the June 2018 BISOS campaign. The ten $\mathrm{SO}_{2}$ sonde v1.1 calibrations performed during BISOS had an $\mathrm{SO}_{2}$ sensitivity of $47.0 \pm 5.8 \mathrm{ppbv} / \mu \mathrm{A}$ and were similar to the laboratory results using dry air $(45.43 \pm 0.17 \mathrm{ppbv} / \mu \mathrm{A})$.

With the anticipated levels of $\mathrm{SO}_{2}$, the sondes were configured to sample at the maximum range of 10-450 ppbv of $\mathrm{SO}_{2}$. Figure 7 shows four distinctive $\mathrm{SO}_{2}$ profiles, and Table 2 includes the VCDs for each flight. No plumes above $5 \mathrm{~km}$ AMSL were detected, at which point reductions in air density significantly impacted the LLOD. All but one of the observed $\mathrm{SO}_{2}$ plumes were below the capping inversion of the planetary boundary layer (PBL). On June 22 (Fig. 7a), the ascent profile shows $\mathrm{SO}_{2}$ below $3 \mathrm{~km}$ AMSL peaking at nearly $100 \mathrm{ppbv}$ and additional features between 3-4 km AMSL peaking at 20-35 ppbv (Tang et al., 2020). The latter peaks were correlated with higher RH, perhaps the result of steam from a vent or the ocean entry points having broken through the inversion. The early afternoon June 28 profile (Fig. $7 \mathrm{~b}$ ) shows the highest concentration ( $325 \mathrm{ppbv}$ ) for a resolved $\mathrm{SO}_{2}$ plume during the BISOS campaign. Typical for the trade winds, HYSPLIT trajectories showed the winds were out of the NE, consistent with the plume's transport from vents in the LERZ or the lava ocean entry points. Although the descent profile from a June 29 early afternoon launch lost the signal at $0.58 \mathrm{~km}$ AMSL, Fig. $7 \mathrm{c}$ shows an $\mathrm{SO}_{2}$ plume over the ocean with a peak concentration of $188 \mathrm{ppbv}$ at $0.74 \mathrm{~km}$ AMSL. HYSPLIT trajectories again showed the winds were out of the NE. Lastly, the $\mathrm{SO}_{2}$ plume detected during the ascent of the June 30 launch (Fig. 7d) exceeded the ULOD between 1-3 km AMSL for the $\mathrm{SO}_{2}$ sonde configuration used. The distorted $\mathrm{SO}_{2}$ enhancement extending above the PBL as determined by the temperature inversion is most likely an artifact of the saturated sonde, similar to what was seen in the dual-sonde profile from Costa Rica (Fig. 4). As the RH remains low above the PBL, it is most likely that the $\mathrm{SO}_{2}$ is contained entirely within the PBL. 


\section{Conclusion and Future Work}

An innovative new method for measuring vertical profiles of $\mathrm{SO}_{2}$ from TBS and free-release balloons was successfully tested and demonstrated in controlled laboratory experiments and during four different field deployments covering $\mathrm{SO}_{2}$ concentrations ranging from 0.5-325 ppbv during flights and up to $940 \mathrm{ppbv}$ during ground measurements. This new method requires three major modifications to the standard ECC ozonesonde: the addition of a positive background current, an $\mathrm{O}_{3}$ removal filter, and a sample dryer. Relative to the previous dual-sonde method, the new method measures $\mathrm{SO}_{2}$ using a singlesonde system (i.e. the $\mathrm{SO}_{2}$ sonde). The $\mathrm{SO}_{2}$ sonde and Thermo $43 c$-TL measurements were strongly correlated during laboratory $\left(\mathrm{r}^{2}>0.99\right)$ and field-based $\left(\mathrm{r}^{2}>0.94\right)$ comparisons. Initial field tests and subsequent laboratory testing of $\mathrm{SO}_{2}$ sonde v1.0 highlighted the need to dry the sample upstream of the $\mathrm{O}_{3}$ removal filter to achieve consistent results. Follow-up field measurements in the Athabasca Oil Sands and Hawai'i clearly demonstrated the improvement in the $\mathrm{SO}_{2}$ sonde v1.1's sensitivity and consistency ( $51 \pm 1.2$ and $47 \pm 5.8 \mathrm{ppbv} / \mu \mathrm{A}$, respectively) as a result of drying the sample.

The $\mathrm{SO}_{2}$ sonde v1.1 offers several advantages over the dual-sonde method, including the ability to measure $\left[\mathrm{SO}_{2}\right]$ independent of $\left[\mathrm{O}_{3}\right]$, the capability of sub-ppbv detection limits, faster response and recuperation time when exposed to larger $\mathrm{SO}_{2}$ plumes, and reduced uncertainty. The lighter weight of the payload requires a smaller balloon and less helium to lift, which may prove advantageous for deployment under some field conditions, particularly where helium supplies are limited. It's compactness and weight can also make it a candidate for small drones and UAV campaigns. Field deployments revealed specific issues and areas for improvement. The present design requires pre-setting the sonde's background current prior to the launch. Thus, some a priori estimates of the plume are required to determine the appropriate background current so that the instrument can measure the full range of $\mathrm{SO}_{2}$ concentrations present. In the current $\mathrm{SO}_{2}$ sonde $\mathrm{v} 1.1$, increasing the ULOD by applying a larger background current also increases the LLOD. Further laboratory experiments are needed to identify the factors that cause the remaining observed variability in the $\mathrm{SO}_{2}$ transmission efficiency in the latest instrument version that includes the sample dryer. Much of the testing and calibration completed to date assessed the complete $\mathrm{SO}_{2}$ sonde system (i.e. sonde, filter, dryer). Building a database of the various individual factors, including pump speeds and filter transmission efficiency, will better characterize the causes of sonde-to-sonde variability and allow future versions of the system to improve performance characteristics so that the system can be made available for operational use.

\section{Author Contributions}

Conceptualization by J.H.F. and G.M. Data curation by J.H.F., A.K., S.L.A., M.G.S., E.K., P.W., G.M., E.C., A.A., and J.A.D. Formal analysis by A.K., S.L.A., S.Y. and P.W. Funding acquisition by J.H.F. Investigation by A.K., S.L.A., M.G.S., and E.K. Methodology by J.H.F. and G.M. Writing - original draft preparation by S.Y. Writing - review and editing by P.W. G.M., J.A.D. and J.H.F. Supervision by J.H.F. 
https://doi.org/10.5194/amt-2022-66

Preprint. Discussion started: 3 March 2022

(C) Author(s) 2022. CC BY 4.0 License.

(c) (i)

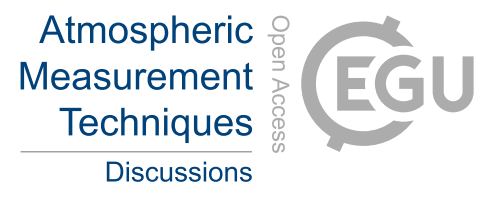

324 Conflict of Interest: The authors declare that they have no conflict of interest.

\section{Acknowledgments}

326 This work was supported by NASA grant numbers NNG11HP16A and 80NSSC18K1061. We especially appreciate our 327 collaboration with En-Sci in advancing this work. We would also like to thank Mark Gordon of York University and David 328 Tarasick of Environment Canada for their invitation and assistance with the deployment to Ft. McMurray, to Henry Selkrik 329 and Holger Vomel from the TicoSonde Project for their support in the Turrialba Volcano testing campaign. A special thanks 330 to Principal Darlene Javar of Na'alehu Elementary School and its teachers, staff, and students for letting us install equipment 331 on a roof and helping us with a launch. 
https://doi.org/10.5194/amt-2022-66

Preprint. Discussion started: 3 March 2022

(c) Author(s) 2022. CC BY 4.0 License.

(c) (i)

\author{
Atmospheric \\ Measurement \\ Techniques \\ Discussions
}

Table 1: Averaged $\mathrm{O}_{3}$ and $\mathrm{SO}_{2}$ concentration measured by the $\mathrm{SO}_{2}$ sonde version 1.0 and Thermo instruments during different 336 stages of testing indicated in Fig. 1.

\begin{tabular}{ccccc}
\hline & $\begin{array}{c}\mathrm{O}_{3} \text { Thermo } \\
(\mathrm{ppbv})\end{array}$ & $\begin{array}{c}\mathrm{O}_{3} \text { Sonde } \\
(\mathrm{ppbv})\end{array}$ & $\begin{array}{c}\mathrm{SO}_{2} \text { Thermo } \\
(\mathrm{ppbv})\end{array}$ & $\begin{array}{c}\mathrm{SO}_{2} \text { Sonde } \\
(\mathrm{ppbv})\end{array}$ \\
\hline $\mathrm{A}$ & $103 \pm 0.4$ & $100 \pm 1.3$ & $-0.3 \pm 0.06$ & $99 \pm 1.8$ \\
$\mathrm{~B}$ & $104 \pm 0.5$ & $102 \pm 0.4$ & $-0.4 \pm 0.06$ & $190 \pm 2.3$ \\
$\mathrm{C}$ & $103 \pm 0.4$ & $100 \pm 0.4$ & $57 \pm 0.40$ & $138 \pm 1.0$ \\
$\mathrm{D}$ & $103 \pm 0.5$ & $98 \pm 0.6$ & $116 \pm 1.9$ & $81 \pm 1.0$ \\
$\mathrm{E}$ & - & - & - & - \\
$\mathrm{F}$ & $-0.13 \pm 0.5$ & $0.53 \pm 0.2$ & $116 \pm 1.4$ & $5.3 \pm 0.1$ \\
$\mathrm{G}$ & $-0.44 \pm 0.4$ & 0 & $58 \pm 0.7$ & $30 \pm 0.6$ \\
$\mathrm{H}$ & $-1.0 \pm 0.4$ & $0.40 \pm 0.04$ & $24 \pm 0.8$ & $67 \pm 0.8$ \\
I & $-1.3 \pm 0.29$ & $1.12 \pm 0.28$ & $-0.25 \pm 0.22$ & $91 \pm 0.7$ \\
\hline
\end{tabular}

Table 2. The $\mathrm{SO}_{2}$ vertical column density (VCD) for profiles shown in Fig. 7 from BISOS in June 2018. For profile c, the descent profile VCD is reported for the flight without extrapolation (shown without parentheses) and using linear extrapolation assuming the $\mathrm{SO}_{2}$ concentration to be $0 \mathrm{ppbv}$ at sea level (shown in parentheses).

Profile $\quad$ Launch Time (UTC) $\quad \mathrm{SO}_{2} \mathrm{VCD}$

\begin{tabular}{lrr}
\hline a (ascent) & $06 / 22 / 201800: 32$ & $8.6 \mathrm{DU}$ \\
b (ascent) & $06 / 28 / 201820: 45$ & $12.5 \mathrm{DU}$ \\
c (descent) & $06 / 29 / 201821: 36$ & $6.2\left(9.8^{*}\right) \mathrm{DU}$ \\
d (ascent) & $06 / 30 / 201820: 48$ & $79.1 \mathrm{DU}^{* *}$ \\
\hline * VCD from extrapolated data & \\
$* *$ Saturation of $\mathrm{SO}_{2}$ at altitudes of 1 to $3 \mathrm{~km} \mathrm{AMSL}$ &
\end{tabular}




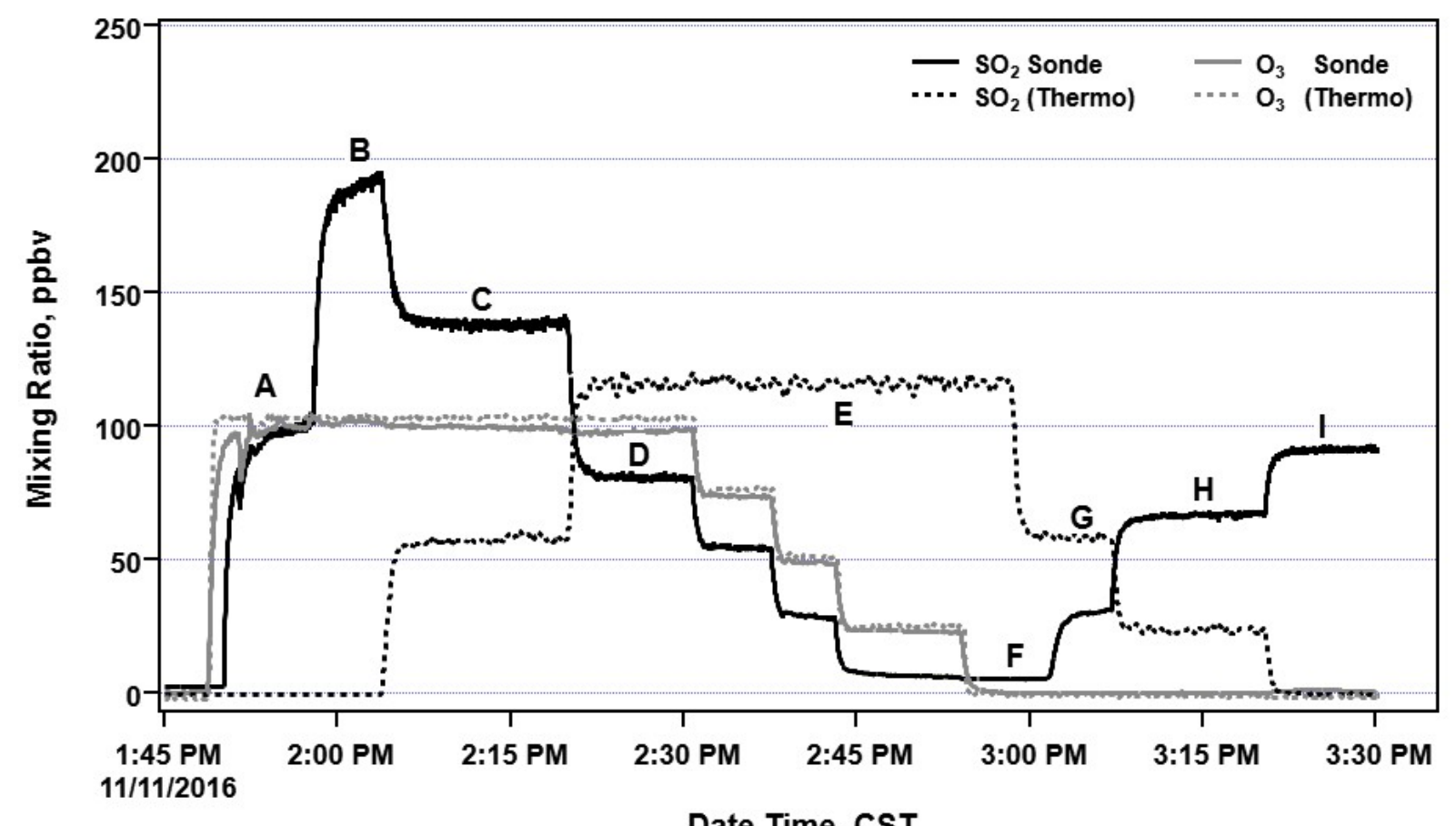

Figure 1: Test of the $\mathrm{SO}_{2}$ sonde v1.0 (without an $\mathrm{O}_{3}$ removal filter) with an applied background current responding to $\mathrm{O}_{3}$ and $\mathrm{SO}_{2}$.

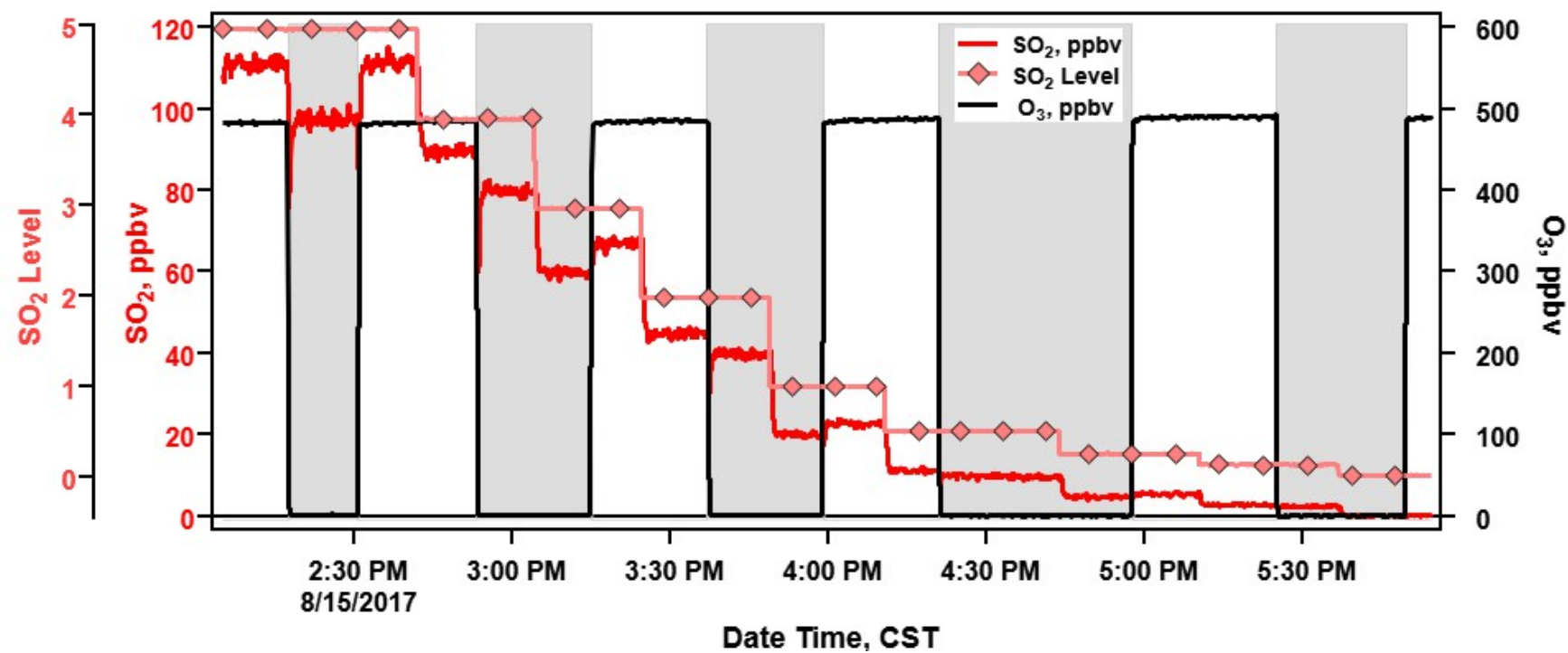

Figure 2: Time of series of a multipoint test of $\mathrm{O}_{3}$ filter removal efficiency and impact on $\mathrm{SO}_{2}$ measurements taken by a Thermo $43 i$ - 

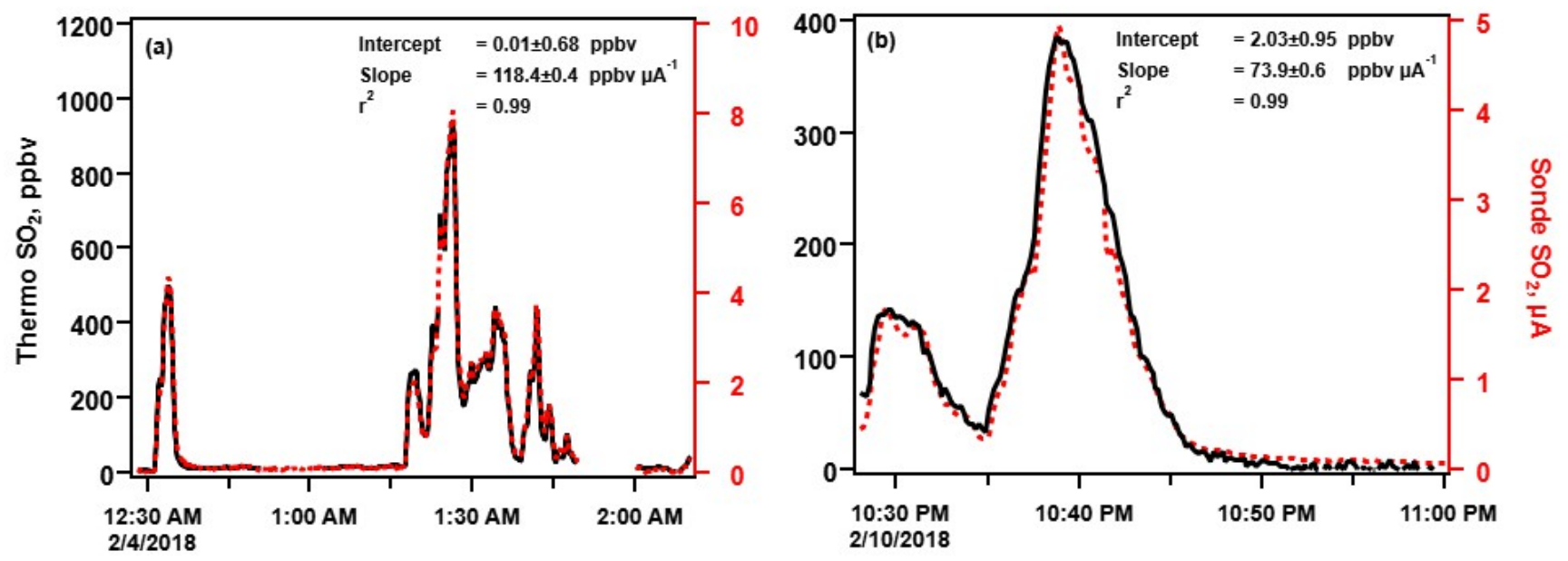

Date Time, UTC

Figure 3: $\mathrm{SO}_{2}$ sonde v1.0 and Thermo Environmental $\mathrm{SO}_{2}$ analyzer measurements at Kīlauea, Hawai'i during H3C for (a) initial $\mathrm{SO}_{2}$ plume encounter on February 3, 2018, and (b) a pre-flight measurement on February 10, 2018, approximately 6 km downwind of Kîlauea's summit crater. 


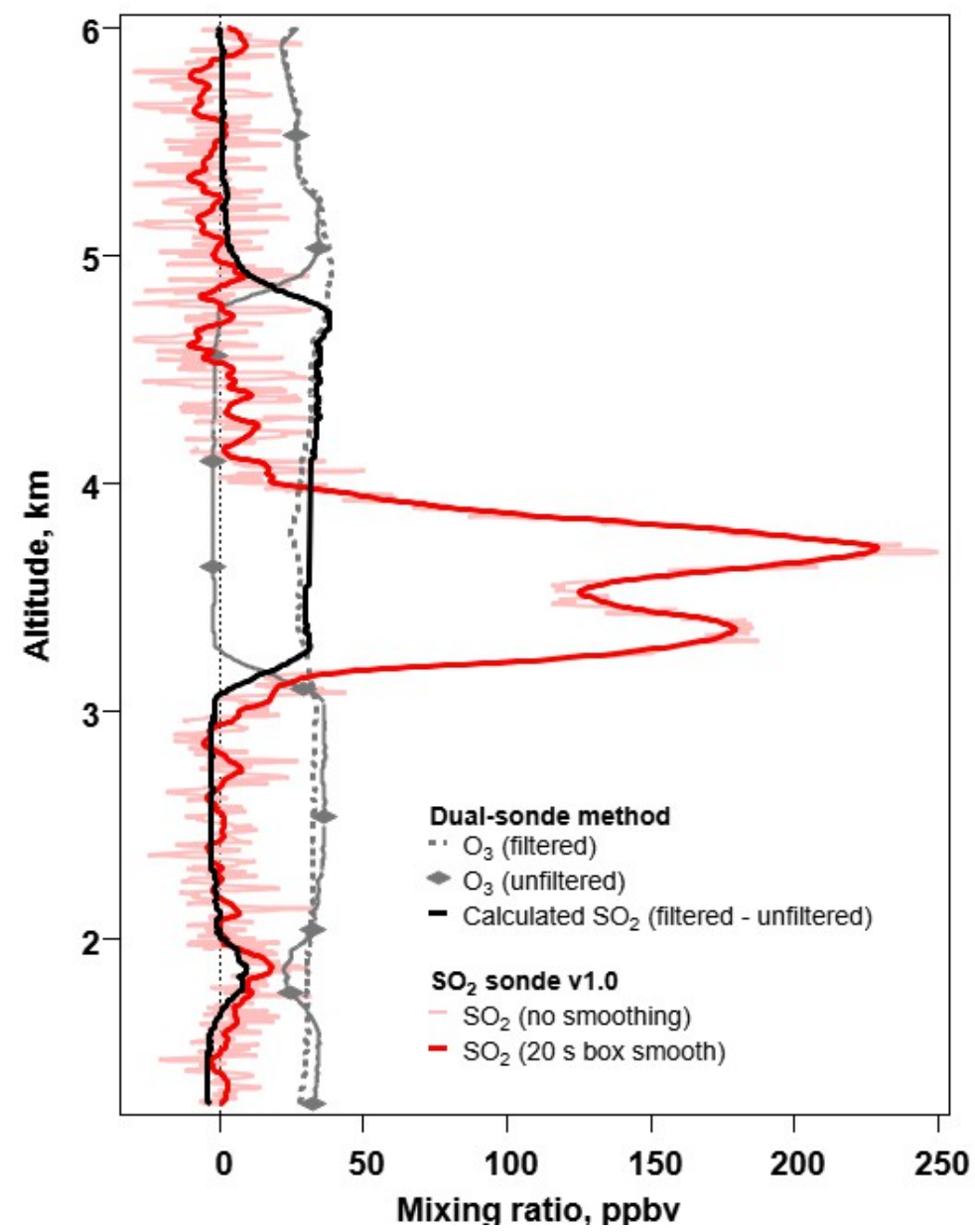

Figure 4: The profiles of a triple-sonde payload, which consisted of a dual-sonde in tandem with an $\mathrm{SO}_{2}$ sonde v1.0, launched from the Universidad de Costa Rica's campus in San Jose (approximately $31 \mathrm{~km}$ downwind of the volcano Turrialba) on March $23,2018$. 


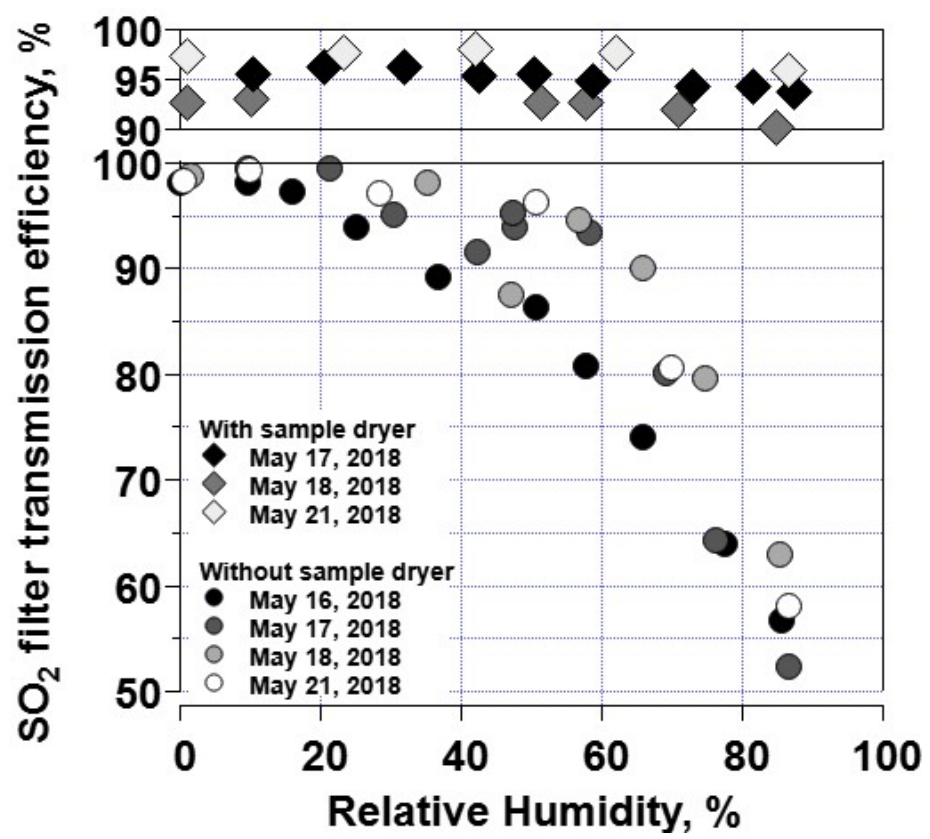

Figure 5: Tests of $\mathrm{SO}_{2}$ transmission efficiency as a function of relative humidity without (circles) and with an upstream sample dryer (diamonds). 


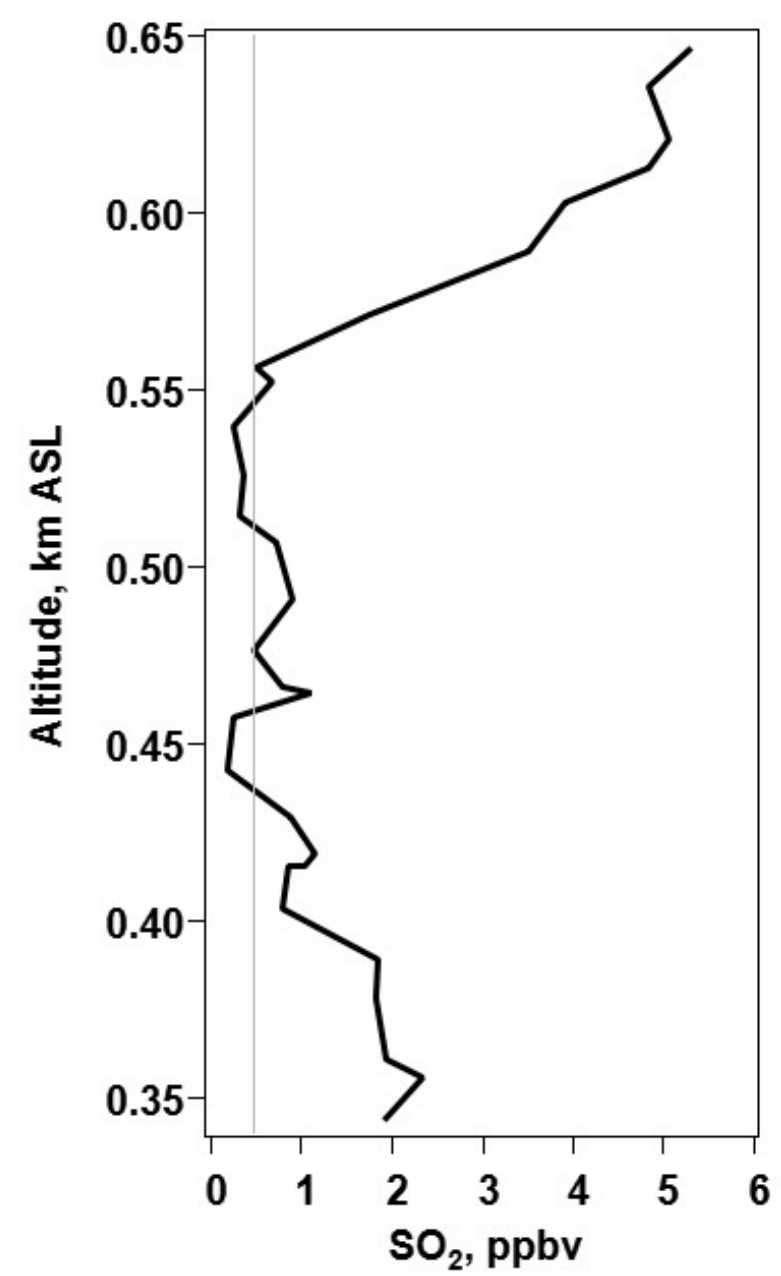

Figure 6: The profile, constructed using $20 \mathrm{~s}$ average changes in altitude (ranging from 1 to $15 \mathrm{~km}$ ), is for a tethered $\mathrm{SO}_{2}$ sonde v1.1 in the Athabasca Oil Sands region of Alberta, Canada. The $\mathrm{SO}_{2}$ sonde background current was $0.5 \mu \mathrm{A}$, and the LLOD was 0.47 ppbv. 
https://doi.org/10.5194/amt-2022-66

Preprint. Discussion started: 3 March 2022

(c) Author(s) 2022. CC BY 4.0 License.

\section{Atmospheric Measurement \\ Techniques \\ Discussions}

Ambient Tempterature, ${ }^{\circ} \mathrm{C}$
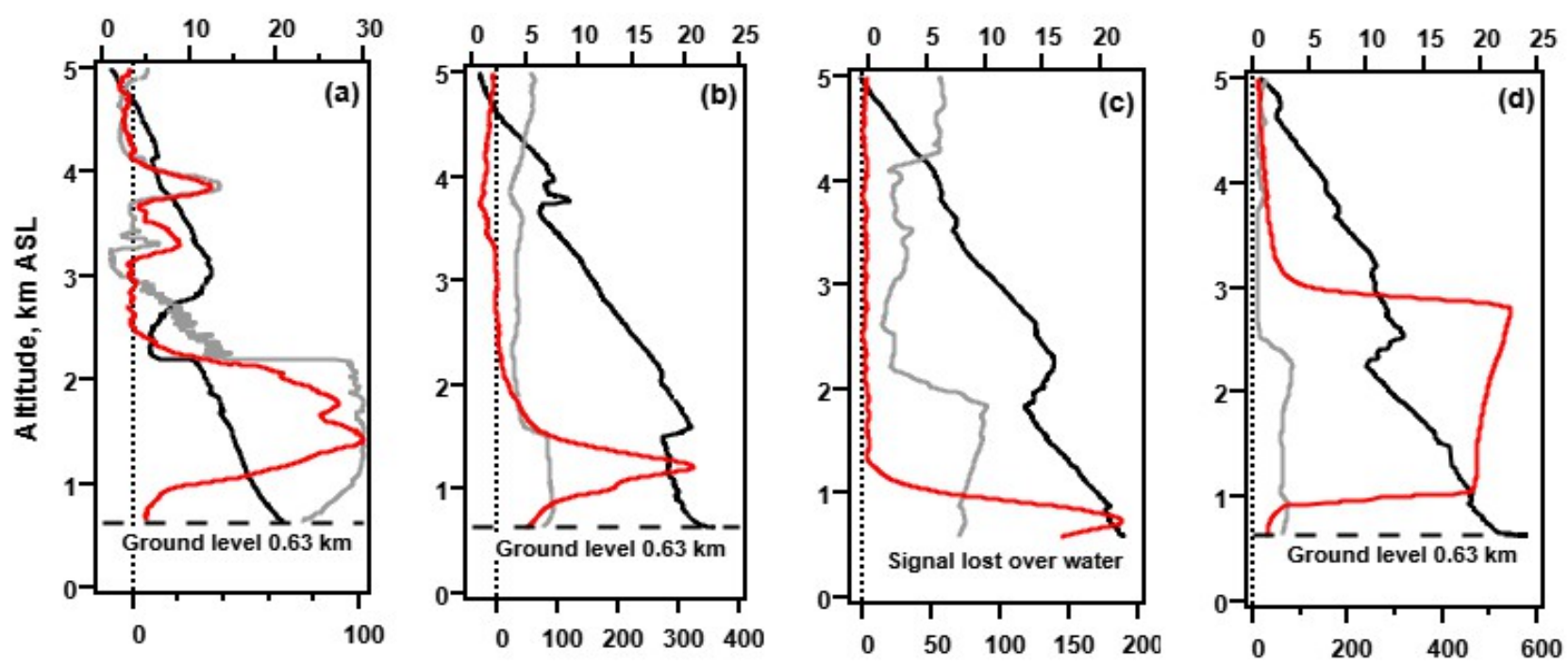

$\mathrm{SO}_{2}$, ppbv; RH, \%

Figure 7: Vertical profiles of $\mathrm{SO}_{2}\left(20 \mathrm{~s}\right.$ box smoothing) from the $\mathrm{SO}_{2}$ sonde v1.1 during BISOS in June 2018 with free-release balloon launches occurring at the Kahuku Ranch on the Big Island of Hawai'i. Profiles are from (a) 6/22/2018 00:32; (b) 6/28/2018 20:45; (c) 6/29/2018 21:36; and (d) 6/30/2018 20:48. All times are UTC. 


\section{References}

Anderson, K. R., Johanson, I. A., Patrick, M. R., Gu, M., Segall, P., Poland, M. P., Montgomery-Brown, E. K., and Miklius, A.: Magma reservoir failure and the onset of caldera collapse at Kīlauea Volcano in 2018, Science, 366, 2019.

Bari, M. A., Kindzierski, W. B., and Roy, P.: Identification of ambient SO2 sources in industrial areas in the lower Athabasca oil sands region of Alberta, Canada, Atmospheric Environment, 231, 117505, 2020.

Bluth, G. J., Doiron, S. D., Schnetzler, C. C., Krueger, A. J., and Walter, L. S.: Global tracking of the SO2 clouds from the June, 1991 Mount Pinatubo eruptions, Geophysical Research Letters, 19, 151-154, 1992.

Carmichael, G. R. and Peters, L. K.: Some aspects of SO2 absorption by water-generalized treatment, Atmospheric Environment (1967), 13, 1505-1513, 1979.

Carn, S., Fioletov, V., McLinden, C., Li, C., and Krotkov, N.: A decade of global volcanic SO 2 emissions measured from space, Scientific reports, 7, 1-12, 2017.

Chen, T.-M., Kuschner, W. G., Gokhale, J., and Shofer, S.: Outdoor air pollution: nitrogen dioxide, sulfur dioxide, and carbon monoxide health effects, The American journal of the medical sciences, 333, 249-256, 2007.

Delmelle, P., Stix, J., Baxter, P., Garcia-Alvarez, J., and Barquero, J.: Atmospheric dispersion, environmental effects and potential health hazard associated with the low-altitude gas plume of Masaya volcano, Nicaragua, Bulletin of Volcanology, 64, 423-434, 2002.

Diaz, J. A., Pieri, D., Wright, K., Sorensen, P., Kline-Shoder, R., Arkin, C. R., Fladeland, M., Bland, G., Buongiorno, M. F., and Ramirez, C.: Unmanned aerial mass spectrometer systems for in-situ volcanic plume analysis, Journal of the American Society for Mass Spectrometry, 26, 292-304, 2015.

Elias, T., Kern, C., Horton, K. A., Sutton, A. J., and Garbeil, H.: Measuring SO2 emission rates at Kīlauea Volcano, Hawaii, using an array of upward-looking UV spectrometers, 2014-2017, Frontiers in Earth Science, 6, $214,2018$.

EPA: National Air Pollutant Emission Trends, 2000.

Flynn, J. and Morris, G. A.: A method for directly measuring so2 and other trace gases by electrochemical cell (ecc) sonde, 2020.

Galle, B., Johansson, M., Rivera, C., Zhang, Y., Kihlman, M., Kern, C., Lehmann, T., Platt, U., Arellano, S., and Hidalgo, S.: Network for Observation of Volcanic and Atmospheric Change (NOVAC)—A global network for volcanic gas monitoring: Network layout and instrument description, Journal of Geophysical Research: Atmospheres, 115, 2010.

Gansecki, C., Lee, R. L., Shea, T., Lundblad, S. P., Hon, K., and Parcheta, C.: The tangled tale of Kîlauea's 2018 eruption as told by geochemical monitoring, Science, 366, 2019.

Kern, C., Sutton, J., Elias, T., Lee, L., Kamibayashi, K., Antolik, L., and Werner, C.: An automated SO2 camera system for continuous, real-time monitoring of gas emissions from Kīlauea Volcano’s summit Overlook Crater, Journal of Volcanology and Geothermal Research, 300, 81-94, 2015. 
Kern, C., Lerner, A. H., Elias, T., Nadeau, P. A., Holland, L., Kelly, P. J., Werner, C. A., Clor, L. E., and Cappos, M.: Quantifying gas emissions associated with the 2018 rift eruption of Kîlauea Volcano using ground-based DOAS measurements, Bulletin of Volcanology, 82, 1-24, 2020.

Kiehl, J. and Briegleb, B.: The relative roles of sulfate aerosols and greenhouse gases in climate forcing, Science, 260, 311314, 1993.

Komhyr, W.: Electrical concentration cells for gas analysis, Ann. Geophys., 25, 203-210, 1969.

Krug, E. C. and Frink, C. R.: Acid rain on acid soil: a new perspective, Science, 221, 520-525, 1983.

Liu, T., Chan, A. W., and Abbatt, J. P.: Multiphase Oxidation of Sulfur Dioxide in Aerosol Particles: Implications for Sulfate Formation in Polluted Environments, Environmental Science \& Technology, 55, 4227-4242, 2021. over the Canadian oil sands as seen from space, Environmental science \& technology, 50, 331-337, 2016. de Moor, J. M., Aiuppa, A., Avard, G., Wehrmann, H., Dunbar, N., Muller, C., Tamburello, G., Giudice, G., Liuzzo, M., and Moretti, R.: Turmoil at Turrialba Volcano (Costa Rica): Degassing and eruptive processes inferred from high-frequency gas monitoring, Journal of Geophysical Research: Solid Earth, 121, 5761-5775, 2016. Morris, G. A., Komhyr, W. D., Hirokawa, J., Flynn, J., Lefer, B., Krotkov, N., and Ngan, F.: A balloon sounding technique for measuring SO2 plumes, Journal of Atmospheric and Oceanic Technology, 27, 1318-1330, 2010. imagery and seismicity to examine degassing and gas accumulation at Kīlauea Volcano, May 2010, Journal of Volcanology and Geothermal Research, 300, 70-80, 2015.

Parker, D. E., Wilson, H., Jones, P. D., Christy, J., and Folland, C. K.: The impact of Mount Pinatubo on world-wide temperatures, International Journal of Climatology: A Journal of the Royal Meteorological Society, 16, 487-497, 1996. connection, Earth and Planetary Science Letters, 507, 50-61, 2019. eruption, and $\mathrm{M} \mathrm{w} 6.9$ earthquake: preface to the special issue, 2020. Pieri, D., Diaz, J. A., Bland, G., Fladeland, M., Madrigal, Y., Corrales, E., Alegria, O., Alan, A., Realmuto, V., and Miles, T.: In situ observations and sampling of volcanic emissions with NASA and UCR unmanned aircraft, including a case study at Turrialba Volcano, Costa Rica, Geological Society, London, Special Publications, 380, 321-352, 2013. 10, 6025-6041, 2010. 
Simpson, I., Blake, N., Barletta, B., Diskin, G., Fuelberg, H., Gorham, K., Huey, L., Meinardi, S., Rowland, F., and Vay, S.: Characterization of trace gases measured over Alberta oil sands mining operations: 76 speciated $\mathrm{C} 2-\mathrm{C} 10$ volatile organic compounds (VOCs), $\mathrm{CO}$ 2, $\mathrm{CH} 4, \mathrm{CO}, \mathrm{NO}, \mathrm{NO} 2, \mathrm{NO}$ y, $\mathrm{O} 3$ and SO 2, Atmospheric Chemistry and Physics, 10, 11931$11954,2010$. and Environmental Medicine, 60, e2-e2, 2003. quality impacts of the 2018 Mt. Kilauea Volcano eruption in Hawaii: A regional chemical transport model study with satelliteconstrained emissions, Atmospheric Environment, 237, 117648, 2020. Pollution Control Association, 17, 403-406, 1967. at Turrialba volcano, Costa Rica, International journal of applied earth observation and geoinformation, 59, 92-103, 2017. Tzortziou, M., Herman, J. R., Cede, A., Loughner, C. P., Abuhassan, N., and Naik, S.: Spatial and temporal variability of ozone and nitrogen dioxide over a major urban estuarine ecosystem, Journal of Atmospheric Chemistry, 72, 287-309, 2015. and O3) variability in South Korean coastal waters, and implications for remote sensing of coastal ocean color dynamics, Remote Sensing, 10, 1587, 2018. Xi, X., Johnson, M. S., Jeong, S., Fladeland, M., Pieri, D., Diaz, J. A., and Bland, G. L.: Constraining the sulfur dioxide degassing flux from Turrialba volcano, Costa Rica using unmanned aerial system measurements, Journal of Volcanology and Geothermal Research, 325, 110-118, 2016. Evidence of high solubility of SO2, Particuology, 11, 41-47, 2013. particulate matter, Chemical reviews, 115, 3803-3855, 2015. 